\title{
Contribution self efficacy and independent learning math toward students' mathematics learning outcomes
}

\author{
Chici Pratiwi ${ }^{1}$, Neviyarni $^{2}$, Solfema ${ }^{3}$ \\ ${ }^{123}$ Universitas Negeri Padang, Padang - Indonesia, (chicipratiwi14@gmail.com )
}

\begin{abstract}
Students' experiencing problems on mathematics learning outcomes at school and many students who did not complete the study of mathematics. Self-efficacy and independent learning math is suspected of influencing factors. This study aimed to examine the contribution of self-efficacy, independent learning math mathematics on learning outcomes. The approach of this research was quantitative with correlational method. The population of this research consists samples 305 and 173 students. The instrument used a Likert scale model. Data were Analyzed using multiple regression. The results showed that there is a contribution of self-efficacy and independent learning math to mathematics learning outcomes.
\end{abstract}

Keywords: self efficacy, independent learning math, mathematics learning outcomes.

\section{Introduction}

Learning is a simultaneous process which is undertaken by individualsto obtain relatively fixed behavior, observable and non-observable behavioral changes that occurred as a result of exercise or experience in their interaction with the environment. One indicator that shows the process of good quality learning is the acquisition of optimal learning outcomes, both the learning outcomes in the form of cognitive, affective and psychomotor. Hasbulah (2012) elaborated that the product of learning is the end result obtained by students after experiencing the learning process that involves changes in ability, understanding, skills and attitudes that can be observed and measured.

According to Permendiknas No. 22 of 2006 on Standard Content explained that mathematics is one of the mandatory lessons. Because, as an universal science that lies a foundation of modern technology development, mathematics has an important role in upgrading various disciplines and advancing human comprehension. Ormrod (2004) explained that mathematics is acknowledged as one of the major source of stress in school learning process. Jbeili (2003) emerged that the high level of anxiety in learning mathematics leads to the dislike of mathematics lessons so that it potentially decreases students' understanding of mathematics.

Based on the observations and information from counseling teachers at SMP Negeri2 Koto XI Tarusan in March 2017, some of the students found that it is difficult to understand mathematics lessons and make them often do not make assignments or homework assigned by teachers in school. As the consequence, some of the student's math score still marked below average. Based on the data can be understood that the problem faced by most students is their mathematics learning result. 
Author discovered that it is necessary to observe the results of learning mathematics students SMP Negeri 2 Koto XI Tarusan to improve learning outcomes optimally.

Daryanto (2009) explains that one of the factors that influence the learning result is the emotional factor of the student that is the students who have positive self-conception, self-confident or selfefficacy, tends to free from frustration, anxious, tense, conflict, and low self. Facts in various studies show that self-efficacy has a significant relation to the achievement of learning outcomes in school. Students with high self-efficacy turn out to have excellent achievements (Schunk\&Meece, 2005).

Bandura (1997) explained that self efficacy will affect one's behavior, effort, persistence, feelings, way of thinking, and behavior. Self efficacy is a person's belief in coordinating his/her own capabilitiesand manifest them by a series of actions in fulfilling the demands of his life. Students with high self-efficacy will see the task as a challenge is not a threat, so they will minimize disruption, implement effective strategies, find a learning partner, not easily desperate and even overcome the failures. While low self efficacy students believe that they will not capable of performing the task even before the task is given as a result, they will carry out learning with doubts and fears.

It can be concluded that self efficacy can bring students to different behaviors among students with equal ability because self-efficacy influences choice, purpose, problem-solving and persistence in business (Sari, 2014). That is, students with high self efficacy believe that students are able to do something to change the events around it, while students with low self efficacy tend to give up easily.

In addition to self-efficacy, other factor that also affects the results of learning mathematics students is the independence of learning mathematics. Learning independence is the nature and ability of students to perform active learning activities which driven by the motive to master something that has been owned competence.

The independence of learning mathematics will be achieved if a student can have the success he has gained. The independence of learning mathematics needs to be improved by students in achievingthe desired learning success. Students who have high independence, then will try to complete the training or tasks given by teachers with the ability they have, otherwise students who have low independence will depend on others to complete the task.

From preliminary data obtained at SMP Negeri 2 Koto XI Tarusan related to self efficacy and independence of students in mathematics learning, phenomenon that happened in field is there are still many students who lack the courage to present themselves in learning mathematics, such as asking or answering questions given by the teacher. In fact, when they are appointed sometimes students can answer questions given by the teacher correctly. However, due to their lack of confidence and uncertainty about their ability to correctly answer questions and fear of being mistaken and laughed at by friends, the students ultimately choose not to answer any questions given by the teacher. At the time of test the students are also discovered to cheat on their friends, and becameless active in following the process of teaching and learning in the classroom, so the value obtained by students during the exam is below average.

It can be concluded the independence of learning mathematics can affects student learning outcomes mathematics. Increasing the independence of learning mathematics students is very important in achieving student learning outcomes in school math. One of the efforts that can be done is through guidance and counseling services.

The phenomenon above shows that the existence of the relationship between self efficacy and the independence of learning mathematics to the students' mathematics learning result, so that researchers feel the need to conduct research to examine and analyze in depth related to the mathematics learning result that is the contribution of self efficacy and the independence of learning mathematics to the learning result mathematics students. 
Based on these explanations can be seen that there is a relevance between the factors and the results of learning mathematics. But how big the contribution between these factors, it is necessary to do research. The results will be used as a reference in the preparation of BK programs. This is the main purpose of this research, because there is no research findings that show how much self efficacy and independence of learning mathematics on student learning outcomes mathematics. The purpose of this study is to examine the contribution of self efficacy and the independence of learning mathematics to the students' mathematics learning outcomes.

\section{Method}

This research is a descriptive quantitative research with correlational method. The population of the research is a sample of 173 students from 305 students of class VII and VIII with proportional stratified random sampling technique. The instrument used is Likert scale model. To know the contribution of two independent variables to one dependent variable, then the data is analyzed by multiple regression. Data analysis was assisted by using SPSS program version 20.00.

\section{Results and Discussion}

\section{Data Analysis Requirements Test}

Test requirements analysis conducted in this research is a test of normality, linearity test, and multicollinearity test. Normality test using Kolmogorov Smirnov method indicated that the research variable data is normally distributed, with Asymp value. Sig. Self efficacy 0.526, and math learning independence of 0.510 . The result of linearity test assumed that the data of self efficacy variable and the independence of learning mathematics with mathematics learning result is linear with Sig. $0.000 \leq$ 0.05 . The result of multicollinearity test discovered that the VIF self efficacy value is 1.242 and the VIF value of math learning independence is 1.242 .

\section{Contribution of Self Efficacy and Independence of Mathematics Learning on Mathematics Learning Outcomes}

Based on the results of tests that have been done, there is a significant positive relationship betweenself efficacy and Independence of Mathematics Learning on Mathematics Learning Outcomes. The results showed that self efficacy and mathematics learning independence correlated significantly to mathematics learning outcomes with $41.4 \%$ contribution. By another words, it can be summarized that self efficacy and independency in learning mathematics are the most influential factors to the final result of learning mathematics.

According to this research can be understood that higher self efficacy and independence of learning mathematics students impacted to better results of learning mathematics achieved by the students. Moreover, self efficacy and the independence of learning mathematics determine the high level of mathematics learning outcomes of students.

The individual who considers himself incapable of completing the task will give up in a short time because he or she does not possess the skills required to complete the task, other wise the students with high self efficacy individual will assume that he has is capable of performing the task and he has feels the ability needed to complete the task (Bandura, 1997). More difficult a task tends to rose higher the desire to be diligent in developing themselves.

Self efficacy improves student's sincerity in performing a task. Self efficacy can also increase the ability and increase the endurance of students in facing various difficulties in learning.

Self efficacy is a good predictor to leverage interest and student learning outcomes in mathematics. However, Students who have a good level of intelligence, personality, and school 
environment that supports it, will not be able to achieve good mathematics learning outcomes without supported by independence of learning mathematics

Self efficacy is a component that plays a role in improving student self reliance which ultimately can improve learning outcomes (Ernawati, 2013). One characteristic of the independence of learning mathematics is that students have the freedom to decide what learning goals are to be achieved and use ful for them.

Based on the above explanation, it substantially emerged the importance of self efficacy and the independence of learning mathematics to improve students' mathematics learning outcomes. One that must be improved and developed in the students is self efficacy and independence of learning mathematics.

Many BK services can be under taken to improve students' mathematics learning outcomes such as information services, content mastery services, guidance activities (Diniaty, 2011), group learning activities (Yusri, 2010), and provision of BK services (Hasibuan, 2008). Based on the results of research, BK services can improve students' mathematics learning outcomes, so BK teachers and mathematics subjects especially play a very important role in providing BK services in order to improve student learning outcomes in school.

\section{Conclusion}

Based on the findings and discussion of the results of research, it can be concluded that the self efficacy and independence of learning mathematics correlated significantly to the results of learning mathematics. The research described that to improve the result of learning mathematics hence student need to improve self efficacy and independence in learning math.

\section{References}

Bandura, A. (1997). Exercise of Personal and Colective Efficacy in Changing Societies. California: Standford University.

Bandura, A. (1977). Self-Efficacy: Toward a unifying theory of behavioral change. Journal of Psychological Review, 84 (2): 191-215.

Daryanto. (2009). Panduan Proses Pembelajaran Kreatif dan Inovatif. Jakarta: AV Publisher.

Depdiknas. (2006). Panduan Pengembangan Diri. Jakarta: Puskur Depdiknas.

Diniaty, A. (2001). Keikutsertaan Siswa pada Lembaga Bimbingan Belajar dalam Kaitannya dengan Motivasi Berprestasi, Kemampuan dan Masalah Belajar serta Peranan Guru Pembimbing di SMUN 1 Padang. Tesis tidak diterbitkan. Program Studi Bimbingan dan Konseling Program Studi Pasca Sarjana. Universitas Negeri Padang.

Ernawati. (2013). Pengaruh Efikasi Diri, Konsep Diri, Aktivitas Belajar dan Kemandirian Belajar terhadap Hasil Belajar Matematika pada Siswa Kelas VII SMP Negeri Kecamatan Somba Opu. Tesis tidak diterbitkan. Makasar: UNM.

Hasbulah. (2012). Pengaruh Komunikasi Keluarga dan Kemampuan Awal IPA terhadap Prestasi Belajar IPA. Jurnal Formatif, 2 (1), 45-47.

Hasibuan, A. (2008). Efektivitas Layanan BK Meningkatkan Mutu Kegiatan Belajar di SMPN 2 Padang. Tesis tidak diterbitkan. Program Studi Bimbingan dan Konseling Program Pasca Sarjana Universitas Negeri Padang.

Jbeili, I. M. A. (2003). The Effect of Metacognitive Scaffolding \& Cooperative Learning on Mathematics Performance and Mathematical Reasoning among Fifth-Grade Students in Jordan. Unpub-Lished Doctoral Dissertation. Penang: University of Science Malaysia. 
Ormrod, J. E. (2004). Human Learning (4 th Edition). Ohio: Pearson.

Yusri, F. (2010). Pengaruh Kegiatan Kelompok Belajar terhadap Peningkatan Mutu Keterampilan Belajar Siswa (Studi Eksperimen pada SMAN 13 Padang). Tesis tidak diterbitkan. Program Studi Bimbingan dan Konseling Program Pasca Sarjana Universitas Negeri Padang.

Yusuf, A. M. (2013). Metodologi Penelitian: Kuantitatif, kualitatif, dan penelitian pengembangan. Padang: UNP Press. 